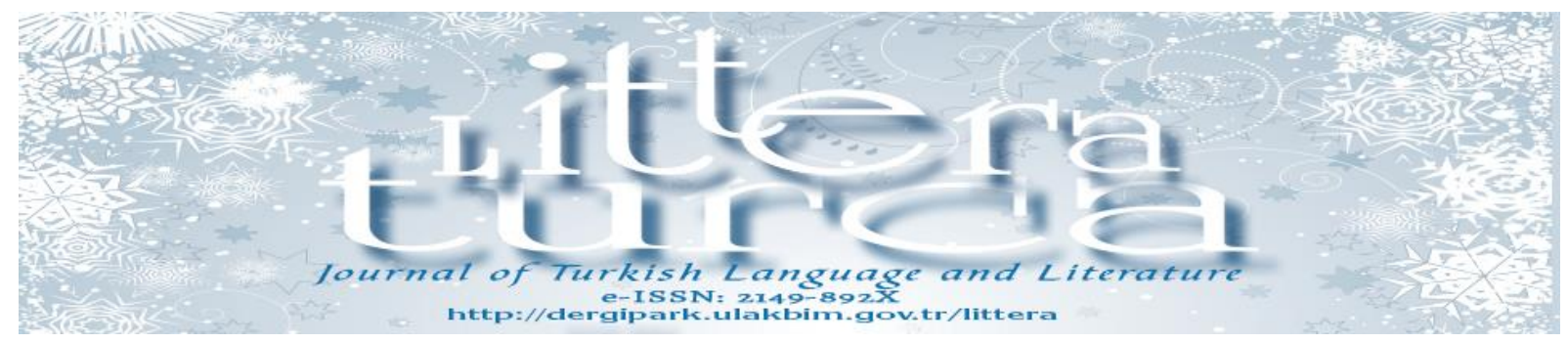

\title{
ADALET AĞAOĞLU’NUN “ÖLMEYE YATMAK” ROMANINDA BAKIŞ AÇISI VE ANLATICI DÜZLEMI
}

\section{Point of Perspective and the Narrator Plane in the Novel of Adalet Ağaoğlu's "Ölmeye Yatmak"}

\author{
Mustafa KARABULUT ${ }^{1}$ \\ Sümeyra GÜNEŞ ${ }^{2}$
}

${ }^{1}$ Prof. Dr., Adıyaman Üniversitesi Fen Edebiyat Fakültesi TDE Bölümü, mkarabulut@adiyaman.edu.tr, orcid.org/ 0000-00016259-0868

2 Yüksek Lisans Öğrencisi, Adıyaman Üniversitesi Lisansüstü Eğitim Enstitüsü, TDE, sumeyragunes34@gmail.com, orcid.org/0000-0001-8441-2819

Araştırma Makalesi/Research Article

\section{Makale Bilgisi}

Geliş/Received: 01.12.2021

Kabul/Accepted: 08.01.2022

DOI:10.20322/littera.1031170

Anahtar Kelimeler Adalet Ağaoğlu, Ölmeye Yatmak, roman, Türk edebiyatı.

\section{Öz}

Adalet Ağaoğlu, Cumhuriyet dönemi Türk edebiyatının önemli romancılarındandır. Birçok türde eser veren Ağaoğlu, önceleri tiyatro türüne yoğunlaşsa da 1970'lerden itibaren hikâye ve romana yönelir. Eserlerinde Türkiye'nin farklı dönemlerinin insan hayatlarına etkilerini ve bireyin iç ve dış dünyasını başarıyla irdeler. Onun romanlarında zaman, teknik ve düşünsel boyut önemli yer tutar. Yazar, kendine özgü bir üslup kullanır. Adalet Ağaoğlu, eserlerinde postmodern edebiyatın kullandığı birçok unsuru kullanır. Eserleri özellikle anlatım teknikleri bakımından zengindir. $\mathrm{O}$, Ölmeye Yatmak romanında Aysel'in yaşamını, düşünceleri ve duygularını yaşamış olduğu dönem çerçevesinde ele alır. Eser bu yönden panaromik bir yapıya sahiptir. Ayrıca Ağaoğlu'nun bu romanı yer yer otobiyografik özellikler de taşır. Romanın başından sonuna kadar başkahraman Aysel'in özgürlük arayışı içerisinde olduğu görülür. Esere bu açılardan bakılınca Türk edebiyatında önemli bir yerinin olduğunu söylemek gerekir. Çoğulcu anlatım tekniğinin kullanılması romanın anlatım gücünü artırır. Yazar, bu şekilde karakterlerin iç ve dış dünyalarını ve dönemin sosyal ve siyasal olaylarını daha etkili biçimde verir. Adalet Ağaoğlu'nun bu romanda ağırlıkta olarak geriye dönüş, iç monolog, bilinç akışı, kolaj, montaj, mektup, diyalog, tasvir, hatıra ve özetleme tekniklerini kullanır. Yazar romanın başkişisi olan Aysel'i ölüm düşüncesine sürükleyen sebepleri farklı bakış açılarıyla daha etkili biçimde anlatır. Bu makalede amaç, Adalet Ağaoğlu’nun Ölmeye Yatmak romanını bakış açısı ve anlatıcı düzlemi açısından incelemektir.

Keywords Adalet Ağaoğlu, Ölmeye Yatmak, novel, Turkish literature.

\section{ABSTRACT}

Adalet Ağaoğlu is one of the important novelists of Turkish literature in the Republican period. Ağaoğlu, who produces works in many genres, has focused on the theater genre at first, but since the 1970s she has turned to stories and novels. In his works, he successfully examines the effects of different periods of Turkey on people's lives and the inner and outer world of the individual. Time, technique and intellectual dimension have an important place in his novels. The author uses a unique style. Adalet Ağaoğlu uses many elements of postmodern literature in her works. His works are especially rich in terms of expression techniques. In his novel Ölmeye Yatmak, he deals with Aysel's life, thoughts and feelings within the framework of the period in which she lived. The work has a panoramic structure in this respect. In addition, Ağaoğlu's novel has autobiographical features from time to time. From the beginning to the end of the novel, we see that the protagonist Aysel is in search of freedom. Looking at the work from these perspectives, it should be said that it has an important place in Turkish literature. The use of pluralistic narrative technique increases the narrative power of the novel. The author also presents the inner and outer worlds of the characters and the social and political events of the period more effectively in this way. In

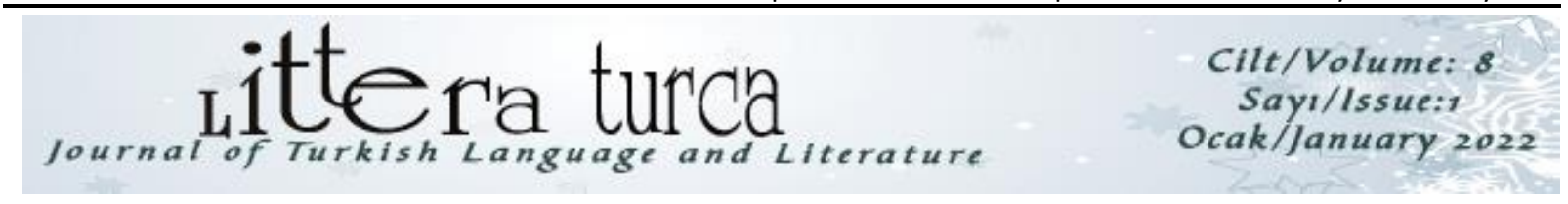


this novel by Adalet Ağaoğlu, she mainly uses the techniques of flashback, internal monologue, stream of consciousness, collage, montage, letter, dialogue, description, memory and summarization. The author more effectively explains the reasons that lead Aysel, the protagonist of the novel, to the thought of death, from different perspectives. The aim of this article is to examine the novel Ölmeye Yatmak by Adalet Ağaoğlu from the point of view and narrator plane.

Atıf/Citation: Karabulut, M., Güneş, S. (2022). “Adalet Ağaoğlu’nun “Ölmeye Yatmak” Romanında Bakış Açısı ve Anlatıcı Düzlemi", Littera Turca, Littera Turca Journal of Turkish Language and Literature, 8/1, 145-160.

Sorumlu yazar/Corresponding author: Mustafa KARABULUT, mkarabulut@adiyaman.edu.tr, Sümeyra GÜNEŞ, sumeyragunes34@gmail.com

\section{GiRiş}

Türk edebiyatının önemli yazarlarından olan Adalet Ağaoğlu (23 Ekim 1929, Ankara - 14 Temmuz 2020, İstanbul), ilk romanı Ölmeye Yatmak'tan (1973) başlayarak sanat hayatının sonuna birçok roman kaleme almıştır. Onun romanlarında modern insanın çıkmazları ve zaman algısı önemli yer tutar. Yazar, ilk kitabından başlayarak hep insanın zamanla ilişkisini yakalamaya çalıştığını söyler. “Örneğin Ölmeye Yatmak, Bir Düğün Gecesi ve Hayır'dan oluşan üçlememe 'Dar Zamanlar' adını verdim, çünkü bu kitaplarda öznel olarak son derece geniş ama nesnel olarak çok dar zaman dilimleri ele alınıyor” (Ağıl, 1996: 20).

Adalet Ağaoğlu, Feridun Andaç’la yaptığı söyleşide, kendisini roman yazmaya yönelten sebepleri açıklar. Yazar, “Cumhuriyet'in analizini yapmak, onu ameliyat masasına yatırmak istediğini; ayrıca zamanla oynadığını ve romanda anlatıcı çeşitlemesi yapmanın, geçmişi, geleceği birlikte tasarlamanın mümkün olduğunu dile getirir" (Apaydın, 2006: 19). Ağaoğlu, birçok eserinde olduğu gibi bu romanında da dar zamanlara sıkışmış insanın trajedisini dile getirir. Yazar, bireysel temalarla beraber sosyal hususlara da yer verir. "Yarım asrı aşan yazıları, güncelliğini korumakta ve günümüz meselelerine ışık tutacak mahiyettedir" (Yaşar, 2015: 3). Bu bağlamda onun romanları genel olarak ferdi ve sosyal temalarla birlikte kurgulanmıştır denilebilir.

Ölmeye Yatmak'ta, Cumhuriyet'in ilk yıllarında kimlik oluşturamayan, kendiliğini oluşturamayan bir kuşağın trajedisi anlatılır. Romanın isminden de anlaşılacağı üzere olay örgüsünde "ölüme yatmak" izleği ön plana çıkar. “Ölüme yatmak ilk etapta bir kaçış unsurunun ipuçlarını gündeme getirir. Ölüme yatmak, kuşkusuz işlenen günahlardan bir çeşit arınma metodudur. Vicdan muhasebesinden yenik ayrılmanın diğer adıdır" (Eronat, 2004: 36). Aysel bir bakıma ölmeye yatarak kendisinden intikam almak ister. Romanın yazarı gibi, başkişi de bir kadındır. Bununla beraber mutsuz ve karamsar bir yapıdadır. Onun mutlu olması aynı zamanda topluma da yansır. "Mutlu kadınlar mutlu aileleri, mutlu aileler de mutlu toplumları oluştururlar. Böylece toplumda bir mutluluk zinciri halka halka genişler" (Doğramacıŏlu, 2018: 227). Romanın başkişisi Aysel, mutluluğu yakalayamayan bir kadın olup kötümser bir yapı gösterir.

Romanı meydana getiren önemli unsurlardan biri kahramanlardır. Kurgunun oluşmasında roman karakterlerinin rolü büyüktür. "Roman yazarı, kahramanları aracılığıyla okurun zekâ ve düş gücünü harekete geçirir. Böylece romanını ilginç hale getirebilir. Bu denenle bir romanın başarısı, kahramanların ne ölçüde inandırıcı ve ilginç

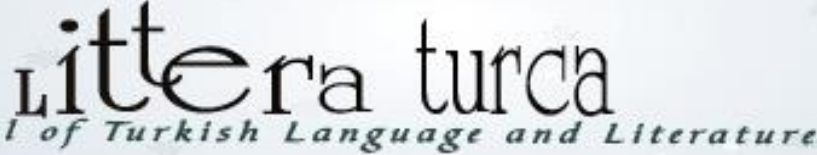


olduklarına bağlıdır" (Yaşar, 2012a: 2076). Bu ifadeler, Ağaoğlu'nun adı geçen romanı içinde söylenebilir. Eserde, başkişi Aysel merkeze alınarak 1938'den 1968'e kadar uzanan bir zaman dilimi içerisindeki olay ve durumlar dile getirilir. Ölmeye Yatmak romanının kurgusu Aysel'in saat 07.22'de bir otele gidip ölmeye yatması ile başlar ve saat 08.49 'da oteli terk etmesiyle sonlanır. Yazar ön planda Aysel'in hayatını sorgulamasını anlatırken arka planda ise ele alınan dönemin siyasi yapısını ve ülkenin içinde bulunduğu durumu gözler önüne serer. Yazar, bunu yaparken sosyal hayatın gerçeklerinden ve hayali unsurlardan yararlanır. "Edebî eserler realite ile muhayyel arasında bir noktada gider gelirler" (Doğramacıŏlu, 2011: 405). Bu romanda da gerçek ile hayali kurgular birlikte ele alınmıştır.

Romanda başkişi Aysel kendisiyle bir içsel diyalog halindedir. Onun iç dünyası karmakarışık bir vaziyettedir. Roman, bu karakter vasıtası ile başka kişilerin iç dünyalarına da ışık tutar. “Aysel, eğitim, özgürlük ve modern aydın kadın olmak için savaşmıştır. Roman, eski ile yeni, geleneksel ile modern arasındaki mücadeleyi, Cumhuriyet'in reformlar sonrası dönemini ve Cumhuriyet'in ideolojilerini ele almaktadır" (Kontselidze, 2021: 66). Yazar, bu bağlamda toplumun bu ideolojileri nasıl karşılayacağını anlatmak için başkişi aracılığıyla irdelemeye çalışır.

Aysel, romanda doçent olarak olay örgüsünde yer alır. 0 , nisan ayının bir sabahında lüks bir otelin on altıncı katında ölmeye yatar. Yaklaşık bir buçuk saat süren bu yatışta Aysel hayatını gözden geçirir ve kendince iç hesaplaşma yapar. Ara bölümler ile Aysel'in Anadolu kasabasından ayrılıp Ankara'ya okumaya gitmesi ve doçent olma süreci verilir. Ayrıca bu bölümlerde Aysel'in ailesi, arkadaşları, dönemin sosyal ve siyasi yapısı da anlatılır. Aysel profesör olan kocası Ömer'i, Engin adlı öğrencisi ile aldatmıştır. Yapmış olduğu hatanın farkına varır, ancak sonradan bunun gayet doğal bir durum olduğunu düşünür. Bu yaşanan olayın olması gerektiğini de dile getirir. Ayrıca romanda Aysel'in hamile olduğu görülür. Fakat çocuğunun babası eşi Ömer değil de öğrencisi Engin'dir. Aysel belki de yaşadığı bu olaylardan kurtulmak için ölmeye yatmıştır. Romanın ilerleyen kısımlarında Aysel'in ölmeye yatmasında etkili olan unsurlara dolaylı olarak değinilmiştir. Ölmeye yatma sürecinde Aysel "okumanın kendisine ne sağladığını" düşünmüştür. Tüm bu olayların eşliğinde Aysel otele geldiği an arkadaşı Aydın'a ulaşmaya çalışır, onu arar ve otele gelmesini söyler. Aydın, Aysel'e karşı birtakım duygular beslediği için onun bu davetini geri çevirmeden kabul eder. Fakat Aysel arkadaşı Aydın gelmeden önce oteli terk edecektir ve onunla hiç karşılaşmamış olacaktır. Aysel, bir saat yirmi yedi dakika süren bu ölmeye yatma sürecinden sonra uyanışa geçer. Kendi ile yapmış olduğu hesaplaşmasını sona erdirir ve yeniden Cumhuriyet ideolojisinin getirmiş olduğu o kadın imajına bürünür. Yatağından çıkar, duş alır ve otelden ayrılır. Böylece roman sona ermiş olur.

Eserde dönemin siyasi tarihine dair bilgiler de verilir. "Romanın geneline bakıldığında çıkarılacak olan asıl ana fikir Cumhuriyet'ten sonra yetişen nesillerin hangi toplum yapısıyla yetiştikleridir" (Aslan, 2019: 22). Bu neslin yaşadığı çatışmalar eserde önemli yer tutar. Ölmeye Yatmak romanında hakim ve kahraman bakış açısı ve

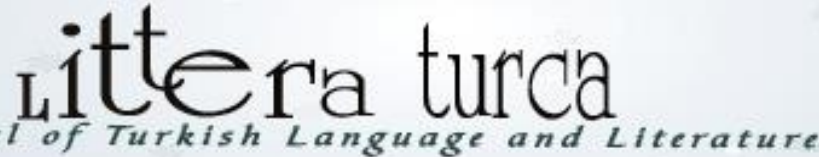


anlatıcı ön plandadır. Romanda çoklu bakış açısı ve anlatım teknikleri kullanılmıştır. Bununla beraber eserde bilinç akışı, iç monolog ve geriye dönüş yöntemlerini ağırıkta kullandığı görülür.

\section{1. ÖLMEYE YATMAK ROMANINDA BAKIŞ AÇISI VE ANLATICI DÜZLEMI}

Roman ve hikâye gibi anlatmaya bağlı türlerde bakış açısı ve anlatıcının önemli yeri vardır. "Hikâyede anlatıcı, olayların öncesini ve sonrasını bildiği gibi, psikolojik tarafının ağır basması sebebiyle, kahramanın iç dünyasına da eğilir. Onların düşündüklerini, gizli kalmış duygularını açığa vurur." (Yaşar, 2012b: 246) Kurmaca metinlerde anlatımın etkisi, yazarın yeteneğine bağlıdır. "Bakış açısı ve anlatıcı düzlemi, entrik kurgunun oluşmasında; bakan hisseden, duyan, idrak eden, olayları kendisine has bir dil ve üslupla anlatan” (Şahin, 2020: 16) sanatçının algı ve aktarım gücünü ortaya koyar:

\footnotetext{
"Bakış açısı, anlatma esasına bağı metinlerde vaka zincirlerinin ve bu zincirin meydana gelmesinde kullanılan mekân, zaman, şahıs kadrosu gibi unsurların kim tarafından görüldüğü, idrak edildiği ve kim tarafından, kime nakledilmekte olduğu sorunlarına verilen cevaptan başka bir şey değildir" (Aktaş, 2005: 78).
}

Bakış açısı ve anlatım teknikleri romanın genel yapısı için önemli unsurlardandır. "Ölmeye Yatmak, farklı anlatım teknikleri ve farklı bakış açılarının yer aldığı bir romandır. Romanın başkişisi olan ve bir üniversitede toplumbilim dersleri veren Doçent Aysel, romanın ana bölümlerinin anlatıcısı konumundadır. Bunların dışında, romanın alt bölümlerinin anlatıcıları, yazarın odaklandığı kişi veya kişilerdir. Bu bölümler, ya (o) anlatıcı tarafından ya da odaklanılan kişilerin bakış açısıyla sunulmaktadır" (Duğancı, 2006: 34).

Ölmeye Yatmak romanı çoklu bakış açısı ile ele alınmıştır. Burada ilk olarak yazar anlatıcı olarak adlandırılan hâkim-tanrısal anlatıcı yer alır. Bu anlatıcı başkişi Aysel ve diğer kişilerin düşünce ve duygu dünyasını ayrıntılı bir şekilde bilir ve okuyucuya aktarır. Anlatıcı üçüncü tekil şahıs olarak görülür. "İtibari bir varlık olan anlatıcı, eserde, yazarın dilini kullanarak ait olduğu âleme ait mekânı, şahıs kadrosunu ve hayat tezahürlerini nakleder veya dikkatlere sunar" (Aktaş, 2005: 89). Romanda yer alan hâkim-tanrısal bakış açısı için şu örnekler verilebilir:

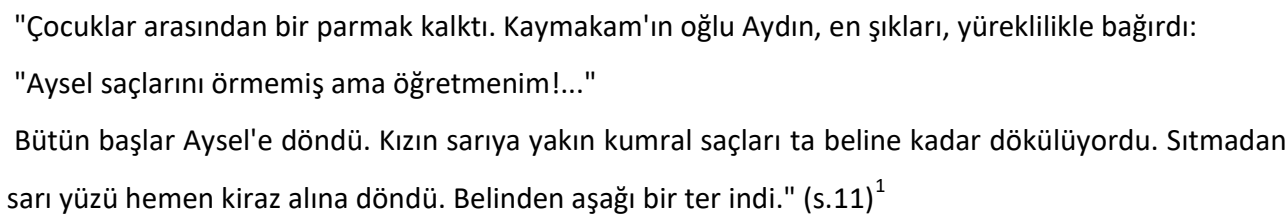

Yukarıdaki parçada görüldüğü gibi hâkim anlatıcı okul müsameresi için hazırlanan öğrenciler arasından Aydın'ın Aysel'i öğretmenine şikayet edişini gösterir. Burada anlatıcı, Aysel'in olaylar karşısındaki vaziyetini ve yapısına dair bazı bilgileri de okuyuculara aktarmış olur. Yazar, hakim anlatıcı ile dönemin sosyo-ekonomik durumu hakkında da bilgiler verir:

\footnotetext{
${ }^{1}$ Ölmeye Yatmak romanından yapılan alıntılar sayfa numarası belirtilerek gösterilecektir. Romanın künyesi için bkz. Kaynaklar. 
"Aysel'in Ulus'un Güzel Sanatlar sayfasını okuduğu yıl, kuru soğanın ve patatesin kilosu 24 kuruş, pırasanınki 16 kuruştur. Tanesi 5 kuruşa satılan mandalina evlerine çok ender giriyor. Muz henüz hiç girmemiştir. Cumartesi öğleden sonraları annesiyle Yenişehir Pazarı'na gidiyorlar." (s.206)

Yazar, romanda hakim anlatııının yanı sıra müşahit (gözlemci) anlatıcıyı da kullanır. Ağaoğlu bu teknikle karakterlerin iç dünyalarını değil, dış görünüş ve davranışlarını yansıtır: "Seyirciler arasında sadece iki kadın, başlarına tavuskuşu tüyleriyle süslü şapkalar giymişlerdi." (s.14)

Hakim ve müşahit anlatııının bakış açıları dışında romanda kahraman anlatıcı da kullanııı. "Kahraman-anlatııı' îtibarî âleme ait her türlü görünüşü dışa aksettirmede aracı durumundadır. Onun, yazarın muhayyilesindeki îtibarî âleme yönelik dikkati, dile ait unsurlarla birleşerek metne vücut verir" (Aktaş, 2005: 93-94). Bu bakış açısı yer yer otobiyografik özellikleri de içinde barındııır. Ayrıca anlatıcı birinci tekil şahıs olarak görülür. Bu bakış açısına şu örnekler verilebilir: "Asansörle tam on altı kat çıktık. On altıncı katta indik. Bana odayı gösterecek oğlanın peşinden yürüyorum. Kısa bir koridor geçti. Bir odanın önünde durdu. Ben de durdum. Kapıyı açtı, içeri girdik." (s.7)

Burada kahraman anlatıcı ölmeye yatma amacıyla gittiği otelden odasına doğru çıktığı anı okuyuculara anlatır: "O çıkınca kapıyı hemen kilitledim. Bütün ışıkları söndürdüm. Çarçabuk soyundum. Köşedeki yatağı açtım. Çırılçıplak içine girdim; ölmeye yattım." (s.7)

Kahraman-anlatıcı romanın ilk sayfasında yer alan bu ifade ile kendisini göstermiştir. Böylece kahramanın burada gerekli koşulları gerçekleştirdikten sonra ölmeye yatar: "Asansörle tam on altı kat indim. Otele faturamı ödedim. Döner camlı kapıyı ittim. Dışarı çıktım. Başkentin puslu nisan sabahı." (s.399) Kahraman anlatıcı romanın sonunda ölmeye yatmaktan vazgeçip oteli terk eder. Burada kahramanın içsel hesaplaşmasının sona erdiği ve yaşama geri döndüğü görülür:

"Bu bakış açısından hareketle kaleme alınmış eserde kahraman-anlatıcı daima ön plandadır. Eser boyunca, onun zaman içinde değişerek gelişmesini anlatabilceği gibi, önce hayatının belirli bir dönemi nakledilir, bazı husûsiyetleri belirtilir; sonra da çeşitli vesilelerle geçmiş dikkatlere sunulur. Her hâl ü kârda 'kahraman-anlatııı'nın ‘ben'i eserin merkezindedir." (Aktaş, 2005: 94)

Böylelikle kahraman anlatıcı otobiyografik karakter özelliğini de göstermiş olur. Romanda Aysel'in 1938 doğumlu olması, liseye devam edebilmek için ailesi ile tartışması ve ailesi tarafından baskıya uğraması, Ankara'da okuması, Paris'e gitmesi ve o tarihlerde evlenmesi gibi durumlar Adalet Ağaoğlu'nun yaşamında olan durumlardır. Böylece Adalet Ağaoğlu Aysel aracılı̆̆ı ile yer yer kendinden de bahsetmiştir.

Romanda üçüncü tekil kişi, kahraman anlatıcıya göre daha azdır: “Üçüncü tekil şahıs ağzından anlatılan bölümlerin azlı̆̆ı, kafa seslerinin bilinç akışı yöntemine yakınlığı, romanın Aysel'in düşüncelerinden ve geriye dönüşlerinden yola çıkarak anlatılması bakımından yeni roman teknikleri anlayışına çok yakın bir çizgide

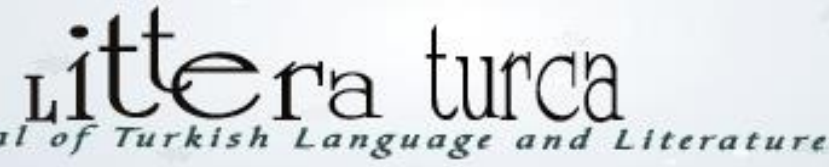


olduğunu söyleyebiliriz" (Yalçın, 2003: 468). Bu bağlamda bireyin duygu ve düşünceleri kendi iç sesinden daha etkili şekilde dile getirilir.

Ölmeye Yatmak'ta yazar, hâkim ve kahraman anlatıcı ile birçok anlatım tekniğini kullanır. Okuyucu bu sayede başkahraman Aysel'i ve beraberindekileri ayrıntılı bir şekilde tanımış olur.

\section{2. ÖLMEYE YATMAK ROMANINDA ANLATIM TEKNIKLERI}

Anlatım teknikleri, edebi türlerde kullanıldığında o türe zenginlik, çeşitlilik, çok seslilik ve derinlik sağlamış olur. Yazar anlatım teknikleri ile bilgi, duygu, düşünce ve hayal dünyasını okuyucuya aktarır. Bunları aktarırken de seçmiş olduğu konuya uygun anlatım tekniklerini kullanır.

\subsection{Geriye Dönüş Tekniği}

Romanda yazar olaylar devam ederken farklı sebeplerle geçmişe ait bilgi vermek için geriye dönüşlere başvurabilir. "Genel anlamda geriye dönüş tekniği, hem romanın yapısının kuruluşunda, hem olayların yüzeysel veya ayrıntılı olarak sunulmasında, hem de kahramanların çizilip tanıtılmasında önemli rol oynayan bir yöntemidir" (Tekin, 2015: 263). Kullanılan geriye dönüş tekniği romanın en egemen anlatım tekniğidir. Ölmeye Yatmak romanında geriye dönüşlerin olduğu kısımlarda yer yer olayların akışı da kesintiye uğrar. "Başkişi konumundaki Aysel de ölmeye yattığı otel odasında, hatırlamalar ya da çağrışımlar yoluyla kronolojiye uymayan bir aktarım gerçekleştirir" (Sazyek, 2021: 288). Bu kullanım, Aysel'in içsel karmaşasını dışa yansıtmada önem taşır.

Eserde ilk geriye dönüş okul müsameresinde canlandırılan bir oyun ile gösterilmiştir. Bu oyunda Aysel kentli kadın bir memuru canlandırır. Bu oyundaki rolü Aysel'in normal yaşamına da sirayet eder. Nihayetinde Aysel Ankara'da yaşayan bir akademisyen olarak karşımıza çıkar. Aysel'in rolüne bürünebilmesi için kostüme ihtiyacı vardır ve bu kostüm arayışı geriye dönüş tekniği ile okuyuculara gösterilir:

\footnotetext{
"Aysel'e yakası kürklü bir manto bulunamamıştı. Bulunan Ertürk'ün ninesi Zişan Hanım'ın gelinliğinden kalma, parlak siyah bir mantoydu. Ama Zişan Hanım o sıralar bir yetmiş boyunda, doksan iki kişi ağırlığındaymış. İşte bu pürtüklü kadife manto, Aysel'in üstünde bütün hoşgörülere karşı direndiği için, yeniden bohçalanıp Zişan Hanım'ın sandığına kalktı." (s.25)
}

Aysel'in kostüm arayışından önce yaşananlar da yazar-anlatıcı tarafından aktarılır. Böylece o yaşananlara ait görme, duyma, koklama gibi durumları görmüş oluruz. Örneğin müsamere için uygun bir ortam hazırlığı yapıldığı anda oyunun sergileneceği kısımda etrafı kaplayan bir koku şu şekilde anlatılır:

"Perdenin gerisinde çocuklar itişip kakışıyorlardı. Toz, yağ, sirke, sidik ve bitotu karışımı bir koku. Okulun her günkü alışılmış kokusunun az daha yoğunu. Kekremsi, ama yıllar geçtiğinde de hâlâ duyulabilen, duyulmasından tat alınabilen bir koku. Bazı zamanlar insanın kendi konusunu sevmesi gibi bir şey" (s.9).

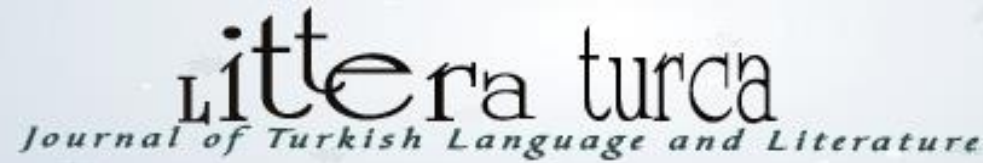


Romanda anlatıcı şimdiki zaman ile geçmiş zaman arasında sürekli mekik dokur. Şimdiki zamanı ele alırken ansızın geçmiş zamana gider. Bu duruma örnek olarak Aysel'in öğrencisi ile olan münasebeti anlatılırken ardından geçmişe dönerek öğretmeninin pazar yerine gidişi okuyuculara aktarılır. Romanda Dündar öğretmenin pazar yerine gidişi şu şekilde verilmiştir: "Dündar Öğretmen okuldan çıkınca bir kere daha pazar yerine indi. Pazar kurulduğu günler üç kez iner alana: Sabah derse başlamadan, öğle tatilinde, bir de işte bu saatlerde; akşamüstü" (s.53) Ölmeye Yatmak romanında geriye dönüş tekniğini sıkça kullanan yazar, Aysel'in bilincinde ve bilinçaltında bulunan duygu ve düşünceleri dışa yansıtır.

\subsection{Tasvir (Betimleme) Tekniği}

Tasvir (betimleme), insana, tabiata, eşyaya veya mekâna dair adeta kelimelerle resim yapma işidir. Bu vesileyle bu nesnelere ait unsurlar görünür hale gelir. "Böylece söz konusu insani tabiat, eşya veya mekân, sadece soyut isim olmaktan çıkar; okuyucunun onu benzerlerinden ayırıp kendi çizgileriyle tanıması sağlanmış olur" (Çetişli, 2004: 100). Ölmeye Yatmak'ta tasvirin önemli bir yeri vardır. Romanın ilk sayfalarında değinilen okul müsamerinde yer alan Başöğretmen şu şekilde tasvir edilir:

"Başöğretmen ellerini arkasına kenetlenmiş, sabırsızca ortalıktaki dağınıklığa bakıyordu. Kolları kısa, soluk, çizgili ceketi, çizgili dokuma gömleği, bol kısa paça, göbeğine dar gelen pantolonuna, çocuk kakası rengindeki kunduralarına rağmen bir başöğretmenden çok, bir cami hocasını andırıyordu."

Bu tasvir beraberinde okul müsameresine gelenler için yapılmıştır. Müsamereye gelenler arasında kadınlar ve erkekler yer almaktadır. Kimi başörtülü, kimi fötr şapkalı, kimi kasketlidir. Gelen seyircilerin ayırt edici özellikleri kaba taslak verildikten sonra müsamerede sergilemiş olduğu hareketlere de yer verilmiştir:

"Okulun sıraları yan yana dizilmiş. Bazı öğrencilerin babaları, anaları, hısım akrabaları, fötrlü, kasketli, başörtülü, sıkmabaşlı; yerlerine oturmuşlardı. Bazıları, erkeklerden bazıları, başlarını açmayı akıl etmişler. Yaşlı kadınlar damalı örtüleriyle yüzlerini kapatıyorlar. İçlerinden on kez, "Allahım sen günah yazma" diye yakarıp dua ederek, üç kere bağırlarına tükürüyorlar." (s.14)

Aysel, yapılan okul müsameresinde Çiçekler, Böcekler ve Kelebekler tablosunu yaptığı an hâkim anlatıcı tarafından şu şekilde tasvir edilir: "Aysel, sarı, benekli kanatlarıyla böcekler ve çiçekler içinde kelebekti." (s.20)

\section{3. İç Monolog Tekniği}

iç monolog (interior monologe), kişinin içsel konuşmalarının, iç hesaplaşmalarının öne çıkarıldığı ve iç dünyasının ele alındığı bir tekniktir. "iç monologda amaç kişinin ruh halini, psikolojisini ve düşüncelerini okuyucuya sunmaktır. Bu anlatım tekniğinde kişi karşııında biri varmış gibi kendi kendine konuşur. Bu süreçte ise okurla eser kahramanı baş başa bırakııır. Böylelikle okurun esere dâhil olması sağlanır" (Aslan, 2019: 152). Burada dilin doğal ve yalınlığı söz konusudur ve genellikle konuşma dili kullanılmaktadır:

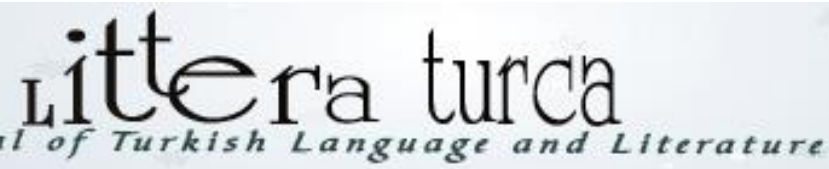


"Bir sahne okuru, kişinin iç yaşamıyla doğrudan doğruya karşılaştırmak için yaptığı konuşmadır. Yazar açıklamalar ya da yorumlar yoluyla araya girmez. (...) Geleneksel monologdan şu özellikleriyle ayrılır: İçerik bakımından, en içten biliçsize en yakın düşüncelerin dile getirilmesidir; doğal nitelikleri bakımından, düzenleyici mantıktan önce gelen, içten düşünceleri doğuşlarına, akışlarına göre sıralayan bir konuşmadır; şekle gelince, sözdizimin en küçük öğelerine indirilmiş dolaysız cümleler kullanılır." (Bowling'den aktaran, Tekin 2015: 289-290).

Ölmeye Yatmak romanında Aysel'in psikolojisini anlatmak için iç monolog tekniğine çokça başvurulur. Romanda başkahraman Aysel'in içsel hesaplaşmasının olduğu kısımlar başarılı bir şekilde verilir. Romanda Aysel'in bir otel odasında ölmeye yatmasıyla birlikte geçirdiği vakitte bu teknik kullanılmıştır:

"Ayrım olmadan elimi çıplak karnıma koymuşum. Parmaklarımla bastırıyorum karnıma. Böyle nasıl anlaşılır? Ölü doğurduğum ilk çocuk. Onun verdiği işaretleri de hiç anımsamıyorum ki. Diyelim gebeyim. Ne yapalım? Otopside anlaşılır. Ardından, gerçeğin yanından bile geçmeyen bir sürü yargıya varılır. Hiçbir yargı gerçek olmayacaktır, evet. Gebeysem gebe olduğum, değilsem değil olduğum dışında, hiç. Karnımda bir çocuk taşıdığımı bilseydim ölüme yatabilir miydim? Öyleyse bununla ilgilenmem gereksiz artık. Bilmiyordum. " (s.74)

Aysel bulunduğu yerde içsel hesaplaşmasını devam ettirirken bir ara uykuya dalar ve uyanıp içsel konuşmasına devam eder. Aysel burada eşini hatırlar ve onun ne yaptığını tahmin etmeye çalışır. O sürekli kendisi ile hesaplaşır ve peşi sıra sorular sorar. Bu peki sıra sorular sorma Aysel'in içsel konuşmalarının tamamında vardır. Biz bu sayede Aysel'in psikolojik yapısı ortaya çıkar:

"Sanırım biraz uyudum. Titremem geçmiş. Tabanlarım yanıyor.

Ne kadar uyudum acaba? Yoksa hiç uyumadım mı? Saate bakmamakta direniyorum. Bütün bir gün ve bir gece geçmişse Ömer ne yapmıştır? Özel hayatımızı dışarı yansıtmayı sevmez. Anneme telefon etmemiştir. Arkadaşlara da. Beklemiştir. Beni ya da benden bir sesi. Belki de hâlâ beklemektedir." (s.113)

Aysel gittiği otel odasında sürekli içsel konuşmalar yapar. "Tabi bu konuşmalar iç monolog şeklindedir. Aysel, iç dünyasında kendi kendine konuşarak okuyucuyu esere katar ve ona sıkıntılarını aktarır" (Aslan, 2019: 152). Hayatını, kendini, çevresini ve birçok şeyi sorgular. O esnada Aysel her şeyle bağlantısını keserek kendisini karanlıklar içinde bir odaya kapatır ve o an şu içsel konuşmaları gerçekleştirir:

"Hangi otel bu?

İçinde uzun yıllar yaşadığım bir kentin, neredeyse birlikte büyüyüp, neredeyse kimliksizliğiyle özdeşleştiğim her kentin bilmediğim bir noktasına asılmışım duygusu içindeyim. Perdeleri sıyırsam karşıma ne çıkacak? Bilmiyor muyum gerçekten? Yoksa korkuyor muyum? Dışarısıyla ilgimin yenilenmesiyle mi korkum?" (s.122)

Romanda Aysel, iç monologlarla iç dünyasını dışa yansıtır. Aysel'in duygu, düşünce ve çatışmaları bu sayede daha etkin biçimde okuyucuya aktarılır.

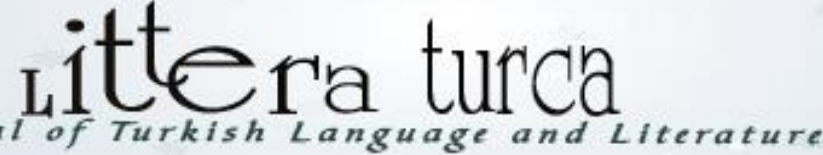




\subsection{Bilinç Akışı (Akımı) Tekniği}

Bilinç akımı, kişinin duygu ve düşüncelerinin düzensiz bir şekilde bir iç konuşma halinde ifade edilmesi demektir. "Ancak buradaki 'iç konuşma' nitelemesini ihtiyatla karşılamak gerekir. Çünkü "bilinç akımı" (stream of consciousness) tekniği, bilinen "iç konuşma" (interior monologue) tekniğinden ayrılır: Ayrılma, biçimlenme mahallinden çok, dil düzeyinde gerçekleşir" (Tekin, 2015: 295). Bu teknik genel olarak psikolojik eserlerde ağırlıklı olarak kullanılmaktadır. Teknik sayesinde bireyin gizli yönleri açığa çıkartılmaktadır. Bilinç akışında kahramanın düşünceleri düzensiz, çarpık ve çağrışımlı bir şekildedir. Burada kahramanın anlattıkları geçmişle şimdiki zamanda arasında ve içsel hesaplaşma halindedir.

Ölmeye Yatmak romanında bilinçakışı tekniğinin önemli yeri vardır. "Aysel'in bilinç akışı ile hem geçmişe yönelmesi hem de kendi ekseninde yaşamı boyu beliren karakterleri yansıtması" (Eronat, 2004: 38), romanın psikolojik bakımdan zengin olduğunu da gösterir. Bu bakımdan yazar, kahramanın "Ruhsal yapısına dair doyurucu bilgi verir" (Yaşar, 2012c: 1139). Bu teknik sayesinde başkişinin iç dünyası daha da ayrıntılı biçimde ortaya konulur.

Başkahraman Aysel romanın ikinci kısmında ne zaman öleceğini düşünür, kendisinin Anna Karenina ve Madam Bovary gibi ölmeye yattığını dile getirir ve o an şu içsel konuşmayı gerçekleştirir:

"Hücrelerim henüz yaşadığımı bağıııp duruyor. Acaba ne zaman öleceğim? Ne zaman tamamlanacak can çekişmesi. Kız öğrencilerimden biri, Anna Karenina ya da Madam Bovary gibi ölüme yattığını görse, kimbilir nasıl güler! Kafa kafaya verip ne dalga geçerler bu tür seçimlerimizle..." (s.31)

Romanın üçüncü bölümünde bilinç akımı tekniğine şu şekilde rastlarız:

"Ben...im, sen...sin, o...dur, biz... Biz'iz. Biz olduk. Ne olduk? " (s.47)

Başkahraman Aysel otel odasındayken birden düğmeleri aklına gelir ve düzensiz bir iç konuşma gerçekleştirmiş olur:

\footnotetext{
"Düğmelerim?.. Öyle ya, soyunurken hiçbir düğmemi çözmedim. Zaten çözüktüler. Bluzumun kolundaki düğmeler. Önündeki düğmeler. $O$ en şık, el işi yeleğimin düğmeleri... Düğmelerim nerde kaldı acaba? Yanılıyor olmalıyım. Neredeyse bütün Ankara'yı yürüdüm. Göğsüm bağrım açık yürümedim ya? Elbet canım; yağmurluğum vardı. Çıplaklığımı örtmüştür. Kopan her şeyimi; sökülen, dağılan, yırtılan..." (s.71)
}

Romanın ilerleyen kısımlarında da bilinç akımı tekniği ile kahramana ait ruh tahlillerini yapılır. Aysel roman boyunca ruhsal bir bunalım içerisindedir ve özgürleşebilmek için ölmeye yatar. $O$, özgürlüğü yaşamakta değil de ölmekte arar ve bunu şu ifadelerle belirtir:

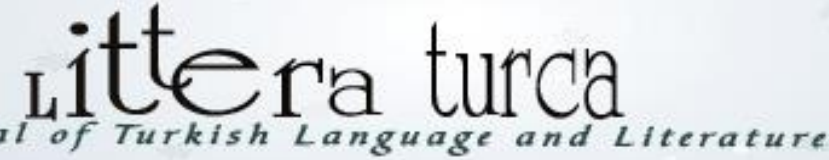


"Birden, sigaram dudaklarımda, çırılçıplak oturduğum koltukta, az önce hesabını gördüğüm omuzlarımı dikiyorum. Kendi gözümde yeniden güzelleşip büyüyorum. Yeniden, bana verilen bütün haklarımı giyiniyorum; bu haklarla yeni haklara uzanıyorum. Türkiye'nin ayrıcalıklı aydın kadını oluyorum yeniden. Ölümümü kendim seçmişim işte. Kendim için de ölüyorum... Devredip soylu nöbetimi..." (s.121)

Aysel, eşini aldattığı Engin ile olan ilişkisi sebebiyle karmaşık ve dağınık duygular içerisindedir. Yazar, Aysel'in bu karmaşık ruh halini ağırlıkta olarak bilinçakışı yöntemiyle verir:

Mali portre. Hala portre diyorlar, koskoca milletvekilleri bile... Yıllık gelir... parti... Kurul... Vietnam... Russel... Sartre... Kemal Tahir... Boris Vian... Tekin Erer... Miting...... Çorabım kaçmış... Yetişkinler eğitimi... Örgün Eğitim... bu notlar neden çıkmamış hala teksirden Nurten Hanım!... kaloriferler yanmıyor... Castro... aslan Fidel...... Al onu sosyalizm için kullan...Evet...hayır... Her sabah bir kaşık bal ye. Güç verir......sen hiç bilmezdin: Bu dünyada ne varsa kadının eseridir, yaa.. Öyle öyle erkeklerini hep yalnız koydun. Sonra da pörsük memeni de bana sömürterek...duymamış gibi olur mu? Duymuşken? Hiçbir şey duymamışken duymuş gibi oluyor da bu neden olmuyor? Duymadım... makineler... Bir matbaanın ortasında...Kocam canlı bir adam benim... Demek bende de yansıyor bu canlılık!." (s.308)

Yukarıdaki cümlelerde Aysel'in iç dünyasındaki çatışmalar ve karmaşa genel olarak birbirinden kopuk ifadelerle verilmiştir.

\subsection{Hatıra Tekniği}

Ölmeye Yatmak romanında anlatıcı diğer tekniklerini destekleyici nitelikte hatıraya da yer vermiştir. Romanda üç ayrı hatıra defteri görülür. Bu üç defterin sahibi kaymakamın oğlu Alper'dir. Hatıra tekniğine şu örnek verilebilir: "Galatasaray'ın orta kısmını pekiyi ile bitirdim. Fakat babam Ankara'ya tayin olduğundan, annem de artık bensiz yaşayamayacağını söylediğinden, hepimiz başkente toplandık." (s.167) Alper'in hatıralarının yer aldığı kısımlarda, roman karakterleri ve olaylar daha etkili şekilde verilir.

\subsection{Montaj Tekniği}

Postmodern romanlarda çokça görülen montaj tekniği, metinlerarası bir uygulamadır. "Montaj tekniği, bir romancının, genel kültür bağlamında bir değer ifade eden anonim, bireysel ve hatta ilahî nitelikli bir metni, bir söz veya yazıyı, 'kalıp halinde' eserinin terkibine belirli bir amaç katması, kullanması demektir" (Tekin, 2015: 264-265). Yazar, Ölmeye Yatmak romanında başkahraman Aysel'in çocukluk ve gençlik yıllarını ele alırken bu tekniği kullanmıştır. Çünkü Aysel Cumhuriyet'in ilk kuşağında çocukluk ve gençlik dönemini geçirmiş ve yazar bu teknik ile o dönemi canlanırmaya çalışmıştır. Yazar roman kahramanlarının geçirmiş olduğu süreci tarihsel boyutlarıyla verir. Bu noktada Ulus gazetesinden direkt veya dolaylı olarak alıntılar yapar.

Romanda Hatay'ın hür olduğunu Dündar Öğretmen'in Ulus gazetesini okumasıyla öğreniriz. Yazar bu gazete ve haber ile romanın yazıldığı tarihsel sürece de değinmiş olur. Okuyucu bu haberi dolaylı yoldan öğrenir. Çünkü direkt bir alıntı yapılmamıştır. "Hatay hür olmuştur. Hatay Millet Meclisi ertesi gün toplanacaktır." (s.32)

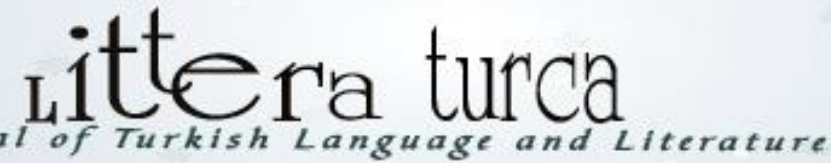


Romanda Kızılay Cemiyeti'nin yapmışolduğu ilan direkt olarak yer almaktadır:

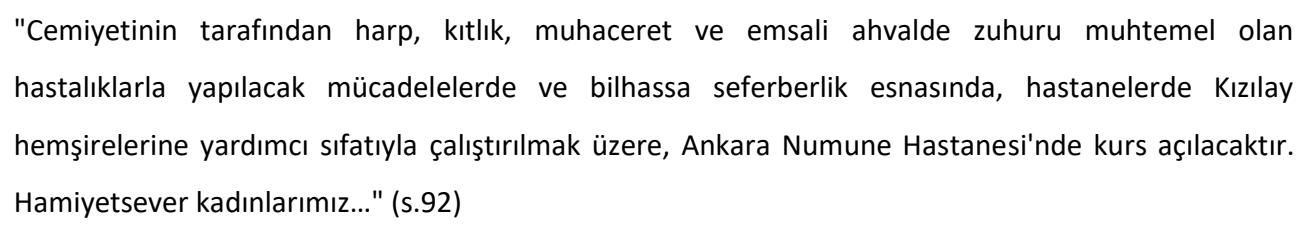

Romanda Ulus gazetesinden birçok alıntı yapılır. Gazetede Türkiye'den ve diğer ülkelerden haberler yer alır. Buna örnek olarak Fransa ve İngiltere'de seferberliğin ilan edilmesi gösterilebilir: "İngiltere ve Fransa'da Umumi Seferberlik ilan edildi." (s.92)

Romanda Hitler hakkında haberlere yer verilerek dönemin siyasi yapısına da değinilmiş olur. Hüseyin Cahit Yalçın'ın Yeni Sabah gazetesinde Hitler hakkında söylemiş oldukları direkt olarak romana aktarılmıştır: "... Avrupa'nın ortasında Töton ırkının Allah tarafından bütün ırklara üstün ve hâkim olarak yaratıldı̆ı̆na imam etmiş yüz milyonluk bir kitle..." (s.93) Yazar, kullandığı montaj tekniği ile metnini besleyerek daha da bütünsel olarak verir.

\subsection{Kolaj Tekniği}

Kolaj, aslında fotoğrafçılıkta kullanılan ve kes yapıştır ilkesine dayanan bir terimdir. Edebiyatta ise bir metnin içine değişik türdeki eserlerden alınan parçaların yerleştirilmesi anlamına gelir. "Bu teknik; mektup, günlük, şiir, şarkı, haber yazısı, makale, ansiklopedi, reklam gibi türlerin desteğiyle yapılarak kahramanların iç ve dış dünyasının daha gerçekçi biçimde hissettirilmeye çalışılmasına dayanır" (Altürk, 2019: 130). Kolajda metin parçalarının, romanın kurgusunda dağınıklığa sebep olabileceği için dikkat edilmelidir. Bununla beraber kolajın özünde yer alan metinler arasındaki tür farklılıkları romanın daha geniş sahalara ulaşmasını da sağlar. "Bir başka deyişle, romanın, tarihsel gelişimi içerisinde genellikle dış gerçekliği yansıtma eğilimini taşıyor olması, bu türe ait eserlerde olay örgüsünün kurgulanışında neden-sonuç ilişkisine dayalı bağdaşık/bütüncül bir metin yapısını temel edinmesine zemin hazırlamıştır" (Sazyek, 2006: 92). Romanda kullanılan kolaj tekniği, metnin bütünselliği açısından önem taşır.

Ölmeye Yatmak romanında kolaj unsurlarına sık rastlanır. Bunlar arasında Cumhuriyet konulu bir şiir, Aydın adlı karakterin anı defterinden alıntılar, Ulus gazetesinden bazı haberler vb. hususlar kolaj tekiniğiyle verilmiştir. Ayrıca Aysel'in söz ettiği bisküvi kutusundaki bazı yazılar bu teknikle aktarılmıştır:

\begin{tabular}{c} 
(Petit-Beure) \\
Small \\
\hline 1922 \\
Biscuits \\
CONSTANTINOPLE
\end{tabular}




$$
\begin{gathered}
\text { H.C } \\
\text { GEUICKNAVORIAN } \\
\text { Biscuits } \\
\text { (Constantionople) }
\end{gathered}
$$

Yukarıdaki örnekte de görüldüğü gibi Ağaoğlu, birçok yapıtında olduğu gibi Ölmeye Yatmak romanında da kolaj tekniğini kullanarak roman dünyasını zenginleştirir.

\subsection{Mektup Tekniği}

Bu teknik romandaki kurgunun daha açıklayıcı olmasına katkıda bulunan ve gerçekçiliği artıran bir tekniktir. "Romandaki şahısların hayatlarındaki önemli kesitleri aydınlatan ve onların bu durumdaki hislerini, duygularını an be an, inceden inceye işleyen, tahlil eden belgeler bir nevi 'iç monolog'lardır" (Kefeli, 2002: 32). Ölmeye Yatmak'ta mektup tekniğinin kullanılması ile başkahraman Aysel'in daha iyi tanıtılması ve olayların inandırıcılığı sağlanmış olur. Romanda toplam on iki mektup bulunmaktadır. Bu mektuplar romanın farklı bölümlerine serpiştirilmiştir. Bu mektupların Aysel, Semiha, Behire, Ertürk, Emin Efendi, Namık ve Aydın'a ait olduğunu götmekteyiz. Mektuplardan on tanesi arkadaşlık ilişkileri ekseninde yazılırken ikisi ise iş ilişkileri ekseninde yazılmıştır. Bu tekniğe örnek olarak Semiha'nın arkadaşı Aysel'e yazmış olduğu mektubun küçük bir kısmı şöyle ifade edilebilir:

"Bir tanecik Kardeşim Aysel,

Güzel mektubunu aldım. Ne güzel yazıyorsun. Teyzengillerin yanındaki hayatını, okulunu, teyzengillerle kestane kavurduğunuz geceleri çok güzel anlatıyorsun. Okudukça ben de seninleymişim gibi oluyorum. Nerde o günler..." (s.63)

Aysel'in Ali'ye yazmış olduğu mektup da bu tekniğe bir örnek olarak verilebilir:

"Kardeşim Ali,

Ne zaman başım sıkışsa nedense aklıma hep siz gelirsiniz. Fakat her seferinde çekinir, vazgeçerim.

Kardeşim, şimdi artık dişimi tırnağıma taktım, ayıbı falan bıraktım size yazıyorum. Sizinle mutlaka görüşmem lazım. Benim için hayati bir mesele. Pazartesi diplomamı almak bahanesiyle Kız Lisesi'ne gideceğim. Hayır abimde üniversite askerlik kampındayken sizinle daha korkusuzca buluşup konuşabilirim.

Eğer sizin için de büyük bir engel yoksa, beni pazartesi günü saat 10.00 'da Dil-Tarih'in arkasında biraz yukarı doğru, yani eski taşmektebin orada bekleyin. Görüşünce her şeyi anlatırım.

Selamlarımı sunarım kardeşim." (s.295)

Ölmeye Yatmak'ta mektup tarzının önemli yeri vardır. Bu sayede romana yeni anlatıcılar da katılmış olur. Bununla beraber, "Tıpkı günlükte olduğu gibi öyküleme zamanında atlamalar yapılmasına, mektup yazarının gelecekle ilgili beklentilerini dile getirmesine, nesnel/tarihsel zamana dair bilgiler verilmesine olanak sağlar" (Apaydın, 2006: 24). Romandaki mektup türü, yazarı devreden çıkararak karakterleri anlatıcı konumuna getirir.

\subsection{Diyalog Tekniği}

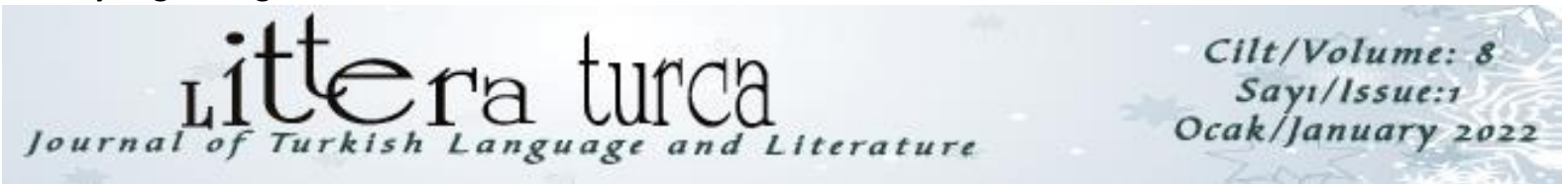


Diyalog tekniğinde anlatıcı romanın dışında kalır ve kahramanların konuşmaları öne çıkar. Diyalog iç diyalog ve dış diyalog olmak üzere ikiye ayrılır. İç diyalogda kahraman karşısında biri varmış gibi kendisiyle konuşurken, dış diyalogda iki veya daha çok kişinin birbiriyle karşılıklı konuşması söz konusu olur.

Romanda Ali ile Aysel'in Hergele Meydanı'nda karşılaşmaları sonucu aralarında şu diyalog geçer:

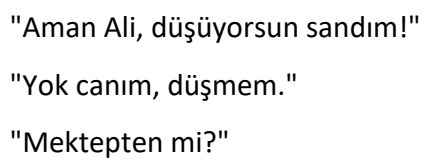

"Evet. Siz nereye böyle, bu saatte?" (s.105)

Romanın ilerleyen kısımlarında Ali ile Aysel'in karşılıklı konuşmalarına sık rastlanır. Konuşmalardan birini şöyle belirtmek mümkündür:

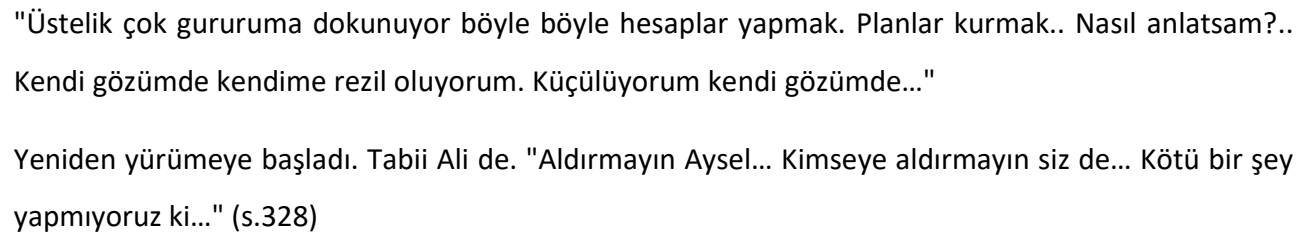

Romanda diyalog tekniği sayesinde olayları gelişimine katkıda bulunulmuş, karakterlerin psikolojik yapısı daha da belirginleşmiş ve anlatımın doğallığını artırmıştır.

\subsection{0. Özetleme Tekniği}

Bu teknikte verilecek bilgiler özet halinde sunulur. Gereksiz cümlelerden yahut olaylardan kaçınılır. "Özetleme tekniği, gereksiz ayrıntıyı silen, dolayısıyla esere derli toplu bir görünüm kazandıran bir yoldur. Bu yöntemle olaylar ve kişiler, bariz yön ve çizgileriyle tanıtılır, anlatılır" (Tekin, 2015: 250).

Ölmeye Yatmak'ta başkahraman Aysel'in öğrencisi Engin ile olan münasebetine kahraman anlatıcı kısaca şu şekilde değinmiştir: "Matbaada işçilik eden bir öğrencimle yattım. Ama çok önceydi bu. Neden yattığımın da öyle uzunboylu üstünde durmuş değilim." (s.114)

Yazar, romanda özetleme tekniğiyle bazı olay veya durumları özetlemekle kalmaz, aynı zamanda karakterler hakkında da bilgiler verir. Bu teknik ile karakterlerin yaşamları daha belirgin biçimde verilmiş olur. 


\section{SONUÇ}

Anlatım teknikleri bir edebi metni vücuda getiren önemli unsurlardandır. Yazar okuyucuya anlatmak istediği duygu, düşünce veya durumları anlatım teknikleri ile aktarır. Adalet Ağaoğlu'nun "Dar Zamanlar" üçlemesinin ilk romanı olan Ölmeye Yatmak, 1973 yılında yayımlanır. Yazar, eserin merkezine aydın ve özgürleşme çabasında olan Aysel'i alır. Kurgu başkahraman Aysel'in etrafında şekillenerek okuyuculara aktarılır. Yazar, bu romanda birçok anlatım tekniğini kullanır. Romanda öne çıkan anlatım teknikleri bilinç akışı (akımı), iç monolog, özetleme, diyalog, tasvir, mektup, hatıra, montaj ve geriye dönüştür. İç monolog ve bilinç akımı teknikleri ile başkişinin iç dünyası ve psikolojik yapısı etkili biçimde dışa yansıtılır. Bu sayede Aysel'i ölmeye yatmaya, bir nevi intihara, sürükleyen sebepler daha iyi anlaşılır. Diğer anlatım teknikleri ile de roman zenginleştirilir. Yazar Aysel'in kişiliğini ortaya koymak ve zihninden geçenleri açığa çıkarmak amacıyla çoklu bakış açısı ve anlatım tekniklerine başvurur. 


\section{KAYNAKÇA}

Ağaoğlu, Adalet (2014). Ölmeye Yatmak. İstanbul: Everest Yayınları.

Ağıl, Nazmi (1996). “Zaman Kırıcı Romantik Bir Viyana Yazı́nda Zaman”, Adam Sanat, Ağustos 1996, S.129

Aktaş, Şerif (2005). Roman Sanatı ve Roman incelemesine Giriş. Ankara: Akçağ Yayınları.

Altürk, Zafer (2019). Adalet Ağaoğlu’nun Romanlarında Modernist Unsurlar, Yüksek Lisans Tezi, Van Yüzüncü Yıl Üniversitesi Sosyal Bilimler Enstitüsü, Van.

Apaydın, Mustafa (2006). “Adalet Ağaoğlu’nun Dar Zamanlar Üçlemesinde Zaman Kurgusu Üzerinde Bazı Değerlendirmeler", Ç.Ü. Sosyal Bilimler Enstitüsü Dergisi, Cilt 15, Sayı 2, 2006, 17-38.

Aslan, Oya (2019). “Adalet Ağaoğlu'nun Dar Zamanlar Üçlemesinde Postmodern Yansımalar”, Yüksek Lisans Tezi, Ağrı İbrahim Çeçen Üniversitesi Sosyal Bilimler Enstitüsü, Ağrı.

Ayaz, Hüseyin (2009). “Ölmeye Yatmak Romanında Aysel'in Yabancılaşması”, Internotional Journal of Social Science, Volume 2 Issue 2, p. 33-40, Winter 2009.

Bowling, Lawrence E. (1965). “Bilinç Akımı Tekniği Nedir?”, Çev. M. Belge, Yeni Dergi, Sayı: 8.

Çetişli, İsmail (2004). Metin Tahlillerine Giriş-2, Hikâye- Roman- Tiyatro, Akçağ Yayınları: Ankara.

Duğancı, Nihat (2006). Adalet Ağaoğlu'nun Romanları ve Romancılığı, Yüksek Lisans Tezi, Çanakkale Onsekiz Mart Çeçen Üniversitesi Sosyal Bilimler Enstitüsü, Çanakkale.

Doğramacıoğlu, Hüseyin (2011). “Edebî Eserde Tarihin Yeniden Yorumlanması Bağlamında Oflazoğlu Tragedyaları", Turkish Studies - International Periodical For The Languages, Literature and History of Turkish or Turkic, Volume 6/2 Spring 2011, 403-412.

Doğramacıoğlu, Hüseyin (2018). "Şemsettin Sami'nin Kaleminden Kadınlar", Asia Minor Studies, International Journal of Social Sciences, Cilt: 6, Sayı: 12, Temmuz 2018, 221-239.

Eronat, Kamuran (2004). Adalet Ağaoğlu İnsan ve Eser, Doktora Tezi, Dicle Üniversitesi, Sosyal Bilimler Enstitüsü, Diyarbakır.

Karabulut, Mustafa (2012). "Yusuf Atılgan'ın 'Aylak Adam' Romanında Anlatım Teknikleri”, Turkish Studies, Volume 7/1 Winter 2012, p.1375-1387.

Karabulut, Mustafa (2020). Araba Sevdası Romanında Bakış Açısı ve Anlatıcı Düzlemi, (Editör: Veysel Şahin), Ankara: Akçă̆ Yayınları. 
Kontselidze, Sopiko (2021). Adalet Ağaoğlu'nun Ölmeye Yatmak ile Naira Gelaşvili'nin Ayna Kırıkları Romanlarında Kadın Konusu, Kocaeli Üniversitesi Sosyal Bilimler Enstitüsü, Kocaeli.

Kefeli, Emel (2002). Anlatım Tekniği Olarak Mektup, İstanbul: Kitabevi Yayınları.

Sazyek, Esra (2021). Ölmeye Yatmak Romanında Zaman Kurgusu, Romanda Zaman (Romanda Zaman Poetiği Üzerine), Editör: Veysel Şahin, Ankara: Akçağ Yayınları.

Sazyek, Hakan (2006). “Kolaj ve Romandaki Yeri”, Kitap-lık, Mart 2006, s.92-99.

Şahin, Veysel (2020). Romanda Bakış Açısı ve Anlatıcı Düzlemi, (Kitap bölümü), Romanda Bakış Açısı ve Anlatıcı Düzlemi, Editör: Veysel Şahin, Ankara: Akçağ Yayınları.

Yalçın, Alemdar (2003). Çağdaş Türk Romanı (1946-2000), Ankara: Akçağ Yayınları.

Yaşar, Hüseyin (2012a). "Seniha: Uçurumun Dibine Yuvarlanan Bir Genç Kız" Turkish Studies - International Periodical For The Languages, Literature and History of Turkish or Turkic Volume 7/1 Winter 2012, 2075-2085.

Yaşar, Hüseyin (2012b). “Guy de Maupassant'ın 'Sicim'inden Refik Halit'in 'Vehbi Efendi'nin Kuşkusu'na İzler”, Türkiyat Araştırmaları Dergisi, Hacettepe Üniversitesi Türkiyat Araştırmaları Enstitüsü, Yıl: 9, Sayı: 16, Bahar, 233-258).

Yaşar, Hüseyin (2012c). "Azra: Geleneksellikle Modernlik Arasında İdeal Bir Karakter”, Turkish Studies International Periodical For The Languages, Literature and History of Turkish or Turkic, Volume 7/2 Spring 2012, 1133-1146.

Yaşar, Hüseyin (2015). "Samiha Ayverdi'de Doğu-Batı Medeniyeti Meselesi”, Siirt Üniversitesi Sosyal Bilimler Enstitüsü Dergisi, Sayı: 3, 173-190.

Tekin, Mehmet (2015). Roman Sanatı (Roman Unsurları 1), İstanbul: Ötüken Neşriyat. 